\title{
症例報告
}

\section{腹腔鏡手術を施行した直腸 $\mathrm{S}$ 状部子宮内膜症の 1 例}

\begin{tabular}{|c|c|c|c|c|c|}
\hline 植木 & 智之 & 園田 & 寛道 & 清水 智治 & 三宅 \\
\hline 与四 & 大二 & 竹林 & 克士 & 貝田佐知子 & 飯田 \\
\hline 山 & 剛 & 谷 & 眞至 & & \\
\hline
\end{tabular}

\section{内容要旨}

症例は45歳女性. 左下腹部痛を主訴に紹介受診となった，下部消化管内視鏡検査では，直腸S状部 に狭窄所見を認めたものの，粘膜面に上皮性変化を認めず，生検では炎症細胞浸潤のみであった。ま た, 腹部造影CT検査・骨盤部MRI検査では, 子宮頸部背側に境界不明瞭で不整な腫瘤像を認めた。臨 床経過・検査所見により，腸管子宮内膜症を強く疑ったが，通常内視鏡が通過困難なほどの狭窄をき たしている点を考慮して腹腔鏡下高位前方切除術を施行した. 病理組織学的検査では粘膜下層・固有 筋層・外膜組織内に子宮内膜腺と子宮間膜の両成分を認めた。術後経過は良好で術後 9 日目に退院と なった．腸管子宮内膜症における腹腔鏡手術は，従来の開腹手術より低侵襲で詳細に腹腔内を観察す ることが可能であり，有用であると考えられた。

索引用語 : 腸管子宮内膜症, 腹腔鏡手術

\section{はじめに}

腸管子宮内膜症は比較的稀である ${ }^{1)}$ が, 成人女性 の腹痛においては鑑別すべき疾患の一つである. 治療としてはホルモン療法などの保存的治療があ る一方, 器質的変化を伴う症例に対しては外科的 治療が選択される. 今回われわれは, 持続する腹 痛と内視鏡にて高度な狭窄所見を認める直腸 $\mathrm{S}$ 状 部病変に対して腹腔鏡手術を施行し, 腸管子宮内 膜症と診断するに至った症例を経験したので，若 干の文献的考察を加えて報告する.

\section{症例}

患 者: 45歳, 女性.

主 訴: 左下腹部痛.

既往歴：胆囊結石症 (経過観察)。

家族歴：父に胃癌, 祖父に大腸癌.

受付：2016年 5 月 17 日, 採用：2016年 9 月 9 日 連絡先 植木智之 † 520-2192 滋賀県大津市瀬田月輪町 滋賀医科大学外科学講座
現病歴：2014年11月より左下腹部痛, 月経随伴 性の便秘を自覚し, 近医を受診した。血便も認め ていたため, 下部消化管内視鏡検査が施行された が，内視鏡が通過できない高度の狭窄を認めたた め, 当科に紹介受診となった.

入院時現症：身長 $152.0 \mathrm{~cm}$, 体重 $47.9 \mathrm{~kg}$. 眼球結 膜に貧血・黄染を認めず, 体表のリンパ節も触知 しなかった。腹部は軽度膨満・軟で, 左下腹部に 圧痛を認めた。

入院時血液・生化学検査所見：血液検査では貧 血・白血球上昇は認めなかったが, 生化学検査で はCRP $0.40 \mathrm{mg} / \mathrm{dl}$ と軽度上昇を認めた。腫瘍マー カーはCEA・CA19-9・CA125のいずれも上昇を 認めなかった。

注腸造影検査所見: 直腸S状部に狭窄性病変を 認めた. 粘膜面の変化は明らかではなかった (Fig. 1a).

下部消化管内視鏡検査所見 : 高度狭窄によって 通常内視鏡が通過しなかったため, 経鼻内視鏡 (オ リンパス社製，PCF-Q260AI）を使用したところ， 


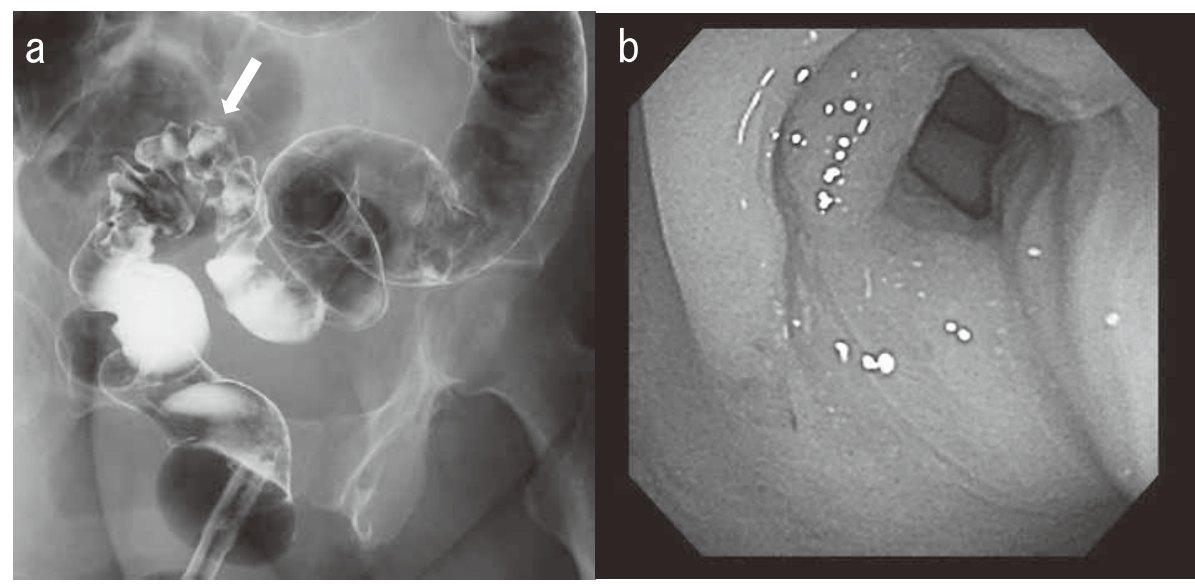

Fig. 1 Barium enema examination showed stenosis in the rectosigmoid (a), Colonoscopy revealed severe stenosis of the rectosigmoid, although the biopsy only found inflammatory cells (b).

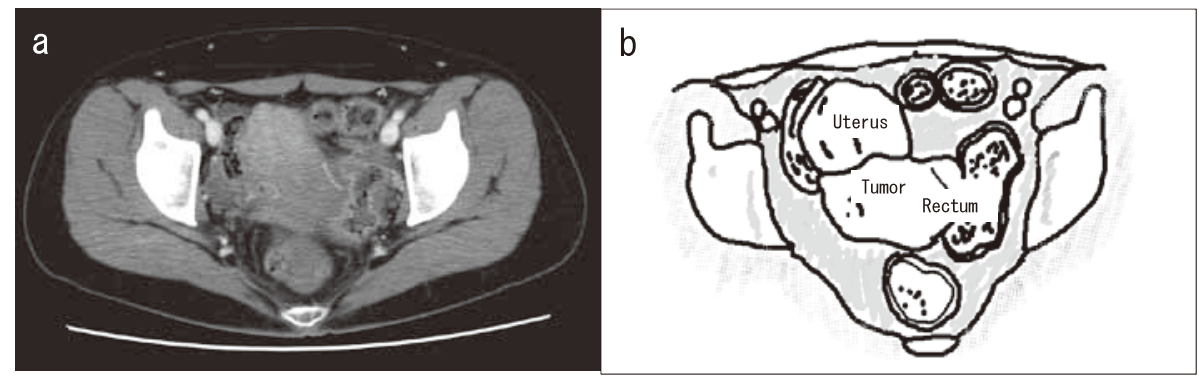

Fig. 2 Abdominal contrast-enhanced computed tomography showed tumor lesions in the anterior wall of the rectosigmoid (a, b: schema).

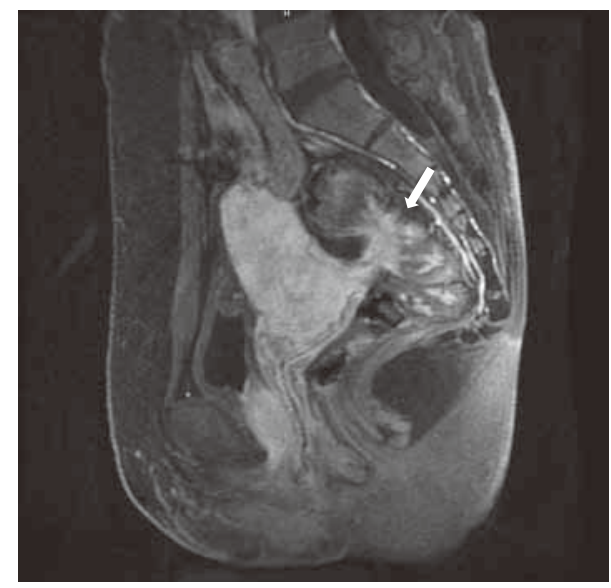

Fig. 3 Pelvic magnetic resonance imaging showed tumor lesions in the anterior wall of the rectosigmoid and the upper rectum behind the uterine cervix suspected of colorectal cancer invasion.
狭窄部を通過することが可能であった．狭窄部の 粘膜面には上皮性変化を認めず, 同部の生検では 炎症細胞浸潤のみであった (Fig. 1b).

腹部造影CT検査所見：上部直腸前壁に境界不明 瞭で不整な腫瘤像を認めた。宮背側と広範に接 しており，一部境界も不明瞭であった (Fig. 2a, b ).

骨盤部MRI検查所見：直腸 $S$ 状部から上部直腸 に前壁中心の半周性に造影される腫瘤陰影を認め, 子宮頸部背側へ連続しており, 直腸癌の子宮頸部 浸潤が疑われた（Fig.3）.

FDG-PET-CT検査所見：上部直腸の限局性の 壁肥厚領域にFDGの集積（SUV Max：3.7〜4.9） を認めた（Fig.4）.

以上, 月経随伴性の便秘を認める点, 注腸造影 検査にて高度な狭窄は認めるが, 粘膜面の変化は 明らかではなかった点, 下部消化管内視鏡検査の 


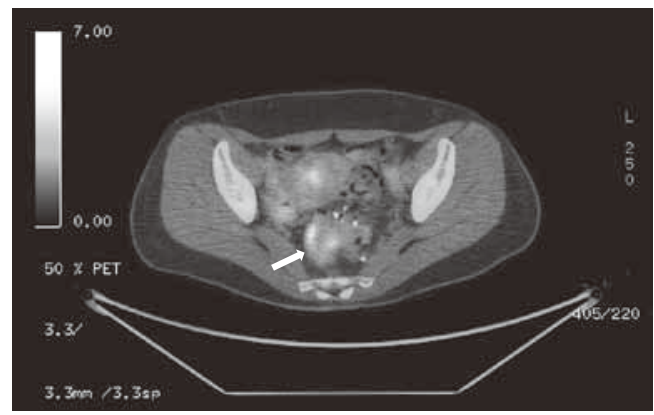

Fig. 4 FDG-PET-CT showed abnormal uptake in the upper rectal wall.

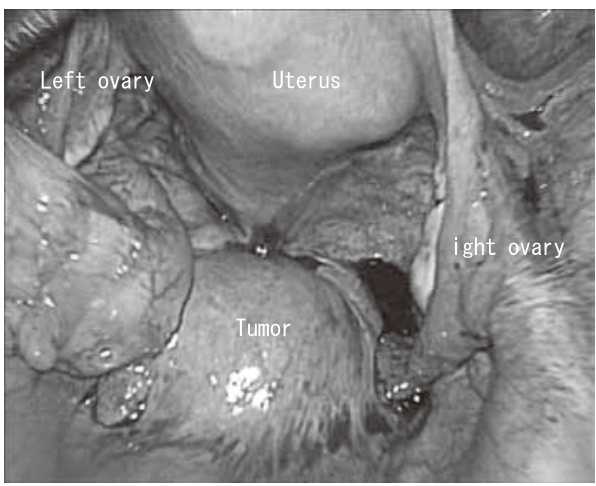

Fig. 5 Operative findings: The sigmoid coIon adhered to the Douglas pouch and had thickened mesenterium.

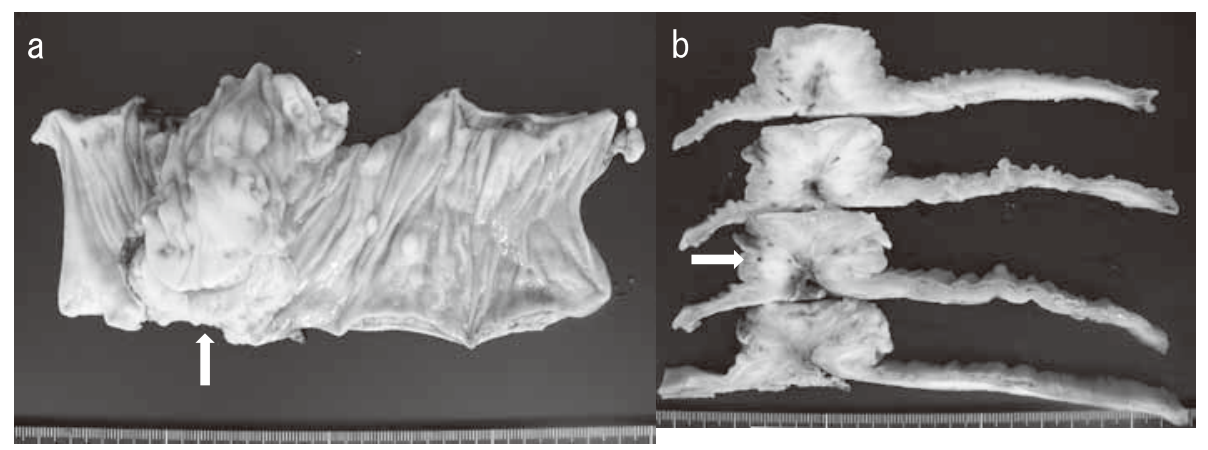

Fig. 6 Macroscopic resected specimens showed the protruded lesions similar to submucosal tumor in the rectosigmoid (a). There are brown spots in the layer of muscularis propria (b).

生検にて悪性細胞が検出されなかった点, 腫瘍マー カーが基準值以下であった点, FDG-PET-CT検 査でのFDGの集積が比較的軽度であった点から， 腸管子宮内膜症を疑ったが, 通常内視鏡が通過困 難なほどの狭窄をきたしている点を考慮して手術 を施行することとした。

手術所見：2015年 7 月腹腔鏡下高位前方切除術 を施行した。全身麻酔下・砕石位で開始した，臍 部に開腹法にて腹腔鏡を扱入し, 左右中腹部, 左 右下腹部の 4 カ所にトロッカーを扱入した. 腹腔 内を観察したが, 左右横隔膜, 腹膜, 胃・小腸な どの消化管に明らかな異常所見を認めなかった. 骨盤腔内では, 両側付属器に異常所見を認めな かったが，S状結腸が屈曲して間膜対側でダグラ ス窩に癒着しており, 可動性は不良で, 一塊の腫 瘤のようになっていた。直腸間膜も肥厚していた
が，閉塞に伴う口側腸管の拡張は軽度であった (Fig. 5 )。 なお, 術前の画像検查所見に反して子 宮背側への直接浸潤所見は認めなかった。確定診 断には至っていなかったため, 癌に準じて手術を 行い，血管処理は下腸間膜動脈根部で行った. ダ グラス窩への線維性癒着は容易に剥離可能であり, 剥離後の腹膜に異常所見を認めなかった。 その後, 炎症性変化を認めない正常腸管で切離, 吻合を 行った。手術時間は 3 時間30分, 出血量は $25 \mathrm{ml}$ あった。

切除標本所見：直腸 $\mathrm{S}$ 状部に粘膜下腫瘍様の隆 起性病変を認めた（Fig. 6a). 肥厚した固有筋層 が周囲組織とともに引き込まれ，固有筋層主体に 出血性変化による点在性の褐色調斑点を認めた (Fig. 6b ).

病理組織学的所見 : 粘膜下層 - 固有筋層 - 外膜 


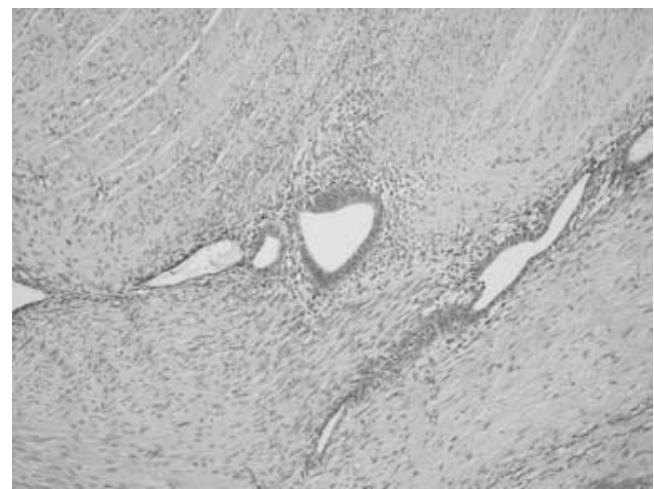

Fig. 7 Histological findings of the resected specimens showed endometrial glands in the layer of muscularis propria (He stained. $\times 100$ ).

組織内に子宮内膜腺と子宮間膜の両成分を認めた (Fig. 7 ). 悪性所見は認めなかった.

術後経過：経過良好で術後 9 日目に退院となっ た. 初診時に認めていた月経随伴性の便秘は軽快 し, 術後 9 力月経過した現在も再発を認めていな い.

\section{考察}

子宮内膜症とは, 子宮内膜もしくはその類似組 織が異所性に発生し機能する病態であり, 成人女 性の約 $10 \%$ に発生するといわれている ${ }^{1)}$. 子宮内膜 症全体の $3 \%$ 37\%が腸管に発生するとされてお り，腸管子宮内膜症の好発部位としてはS状結腸・ 直腸が70\%～90\%と多い ${ }^{122)}$. その発生機序として は，大腸の漿膜側に生着した内膜移植片がエスト ロゲンの影響により周囲組織の線維化を伴いなが ら増殖して腸管の内腔を狭窄させ, 引き続いて起 こる平滑筋化生によってさらに狭窄を悪化させる ためとされている゙).

腸管子宮内膜症の主な症状として, 月経随伴性 の下腹部痛, 便秘, 血便が挙げられる ${ }^{3)}$. 一方, 症 状の発現と月経周期には必ずしも関連性はないと

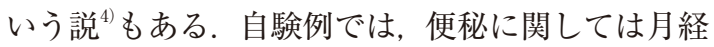
随伴性であったが, 左下腹部痛・血便と月経との 関連性が不明瞭であったため, 診断に苦慮した。 なお，血便は内膜症病巣付近の腸管粘膜から分泌 されるサイトカインなどによって赤血球が渗出す ることにより生じるとされている3.

診断に関しては, 問診, 理学所見の他, 内視鏡,
注腸造影, CTなどの画像検査が必要となるが, 術 前の確定診断は困難な場合が多い。下部消化管内 視鏡検査における粘膜面の発赤, 腫脹, びらんや 壁硬化像，注腸造影における腸管壁外からの圧排 像，狭窄像を認めることはあるが，いずれも典型 的な所見ではない5)。 また, 腸管子宮内膜症の病巣 部は粘膜下組織以下に存在するため, 下部消化管 内視鏡検査においても粘膜面に異常所見を呈する のは稀であり，生検による診断は $10 \%$ 未満とされ ている ${ }^{6)}$. 近年では超音波内視鏡ガイド下穿刺吸引 法を用いた生検で診断率が $40 \%$ とする報告7) や画像 診断におけるMRIゼリー法の有用性が指摘されて いる ${ }^{8)}$ が, 画像診断と生検を併せても術前診断率は 21〜37\%に留まる ${ }^{9)}$. 自験例においても術前検査に て病理組織学的な確定診断が得られなかったが, 月経中の下部消化管内視鏡検査においてびらんな どの異常所見を呈した腸管粘膜から子宮内膜組織

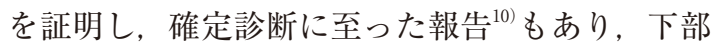
消化管内視鏡検査施行の時期に関して再考の余地 があると考えられた。

治療としては, GnRHアナログ療法, ダナゾー ル，低容量ピル，ジェノゲストなどの保存的治療 と腸管切除などの外科的治療がある ${ }^{11)}$. 保存的治 療抵抗例, 悪性疾患の可能性が否定できない症例, 腸閉塞などの明らかな器質的障害を認める症例, 不妊治療が必要な症例に関しては積極的な手術適 応となる ${ }^{512}$ が, 実際には本疾患の約70\%に手術が 選択されている ${ }^{9)}$. また, 子宮内膜症の $0.3 \sim 1 \%$ に癌化を認める ${ }^{13)}$ 。卵巣外原発の子宮内膜癌の 5 年生存率は $100 \%$ と予後良好とされている ${ }^{14)} も の の$, 治療法の選択に関しては注意を要する。自験例で は鑑別診断として腸管子宮内膜症を第一に考えて いたため, 保存的治療も選択肢の一つであったが, 内視鏡にて高度な狭窄所見を認め, 腸閉塞をきた しつつあった点, 直腸癌の子宮頸部浸潤などの悪 性疾患が完全には否定できない点, 保存的治療が 奏効しても再発する症例や, 前述のごとく経過中 に癌化する症例の報告(5) 15) 17) もある点を考慮して 外科的治療を選択した。

術式の選択に関しては, 悪性疾患も完全には否 定できないとしながらも, 先述のような理由に加 え, FDG-PET-CT検査におけるFDG集積部位が 
腹部造影CT検查における腫瘤像と一致していない 点も踏まえて, 腸管子宮内膜症を第一に考慮し, 腹腔鏡手術を選択した。医学中央雑誌で1999年か ら2014年の期間で，「腹腔鏡手術」「腸管子宮内膜 症」をキーワードに検索（会議録を除く）しえた 報告例のうち，腹腔鏡手術を施行したS状結腸お よび直腸子宮内膜症に自験例を含めた15例につい

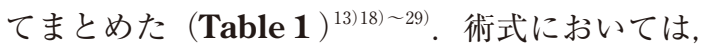
自験例も含めて多くの症例で腸管切除が選択され ているが, 漿膜面に限局した病変では漿膜筋層切 除や楔状切除後に体腔内縫合での修復を施行して いる症例も 3 例認めた.

腹腔鏡手術は低侵襲性・整容性の両面から有用 であるのみならず，さらに追加すべき利点として， 主病巣以外の子宮内膜症病変の検索において従来 の開腹創における限られた視野よりも, 広範に詳 細に観察することができる点が挙げられる ${ }^{28) ~ 30) . ~}$ 離れた 2 力所に同時発症した腸管子宮内膜症や, 術前検査では指摘できなかった無症候性の部位を 含む 3 力所の子宮内膜症の腹腔鏡手術例も報告 $\left.{ }^{29} 30\right)$ されている．腹腔鏡による広範な検索範囲や拡大 視効果の利点により, 卵巣やダグラス窩などの好 発部位のみならず, 小腸や胃などの稀少部位子宮 内膜症の発見にも有用であると考えられる。一方, 直腸・S 状結腸子宮内膜症の場合, ダグラス窩に 強固に癒着し, 剥離操作に難渋することが問題点 である ${ }^{2829)}$. 自験例でのダグラス窩における線維 性癒着は容易に剥離可能であったが, 症例によっ ては出血・手術時間の延長・尿管などの他臟器損 傷が発生する危険性もあるため, 婦人科や泌尿器 科と連携して手術を行うことや必要に応じて術前 に尿管ステントを留置するなどの処置を追加し, 安全に手術が施行できるように留意すべきである と考える.

子宮内膜症の術後管理に関しては, 低用量エス トロゲン・プロゲステロン製剤（LEP製剂）の長 期投与により，卵巣子宮内膜症性囊胞や骨盤痛の 再発が抑制されることが報告されている ${ }^{31)}$. 術後 の再発予防のためにも, 積極的な挙児希望がない 症例にはLEP製剤の服用が推奨される。

利益相反：なし

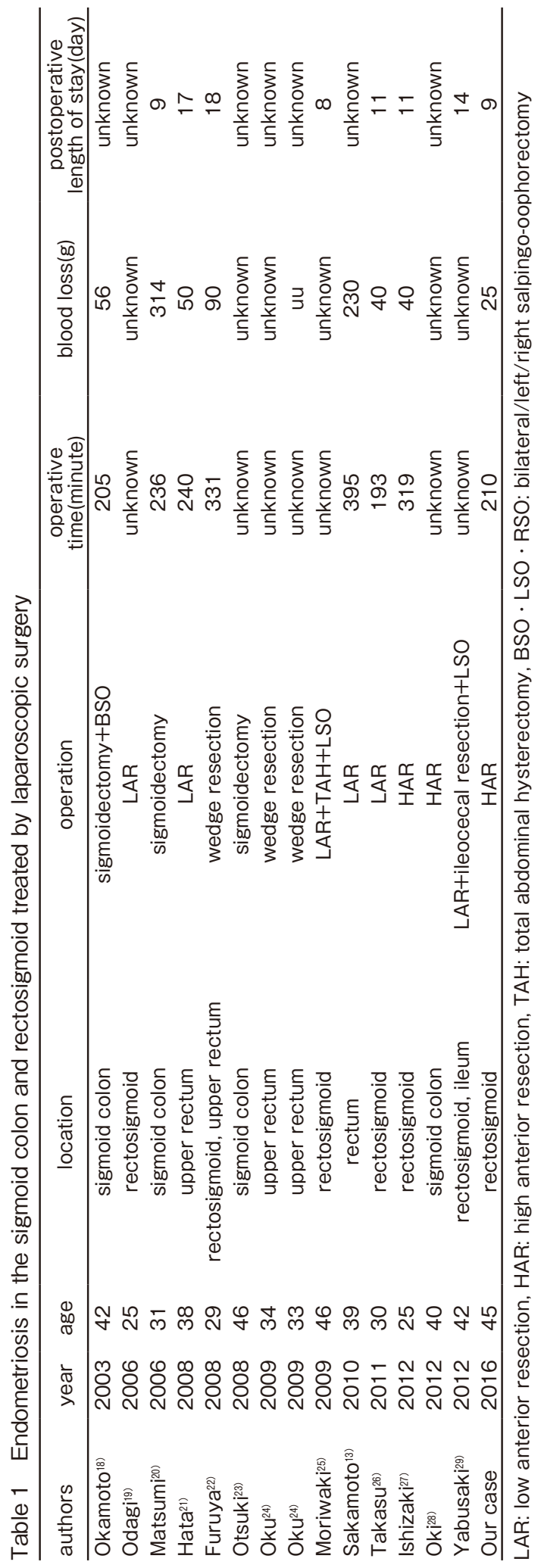




\section{文献}

1）小平 進：腸管子宮内膜症の病態. 胃と腸 33 : 1323-1328, 1998

2) Jubanvik KJ, Comite F : Extrapelvic endometriosis. Obstet Gynecol Clin North Am Jun 24 : 411440, 1997

3）武内裕之, 坂本一博: 子宮内膜症消化器疾患に対 する腹脘鏡下手術. 日鏡外会誌 $12 ： 275-283,2007$

4) De Ceglie AD, Antonella DC, Claudio B, et al: Acute small bowel obstruction caused by endometriosis: A case report and review of the literature. World J Gastroenterol 14:3430-3434, 2008

5）武田 理, 山本裕介, 喜久本藍, 他：GISTとの 鑑別を要した腸管子宮内膜症の 1 例。日エンドメ トリオーシス会誌 36：171-175, 2015

6）遠藤光史, 勝又健次, 森 康治, 他：腸閉塞を発 症した回腸子宮内膜症の 1 例. 日本大腸肛門病会 誌 $60 ： 186-190,2007$

7) Pishvaian AC, Ahlawat SK, Haddad NG, et al : Role of EUS and EUS-guided FNA in the diagnosis of symptomatic rectosigmoid endometriosis. Gastrointest Endosc 63:331-335, 2006

8) Takeuchi H, Kuwatsuru R, Kitade M, et al: A novel technique using magnetic resonance imaging jelly for evaluation of rectovaginal endometriosis. Fertil Steril 83:442-447, 2005

9）桐井宏和, 天野和雄, 瀬古 章, 他 : 両側気胸を 併発した腸管内膜症の 1 例 腸管子宮内膜症本邦報 告例 90 例の検討を含めて. 日消誌 $96: 38-44$, 1999

10）松隈則人, 松尾義人, 鶴田 修, 他：腸管子宮内 膜症の 2 例 本邦報告例 78例の検討を含めて. Gastroenterol Endosc 31:1577-1583, 1989

11）佐藤玲南, 吉田 浩, 渡邊英樹, 他：腸管子宮内 膜症 3 症例の臨床的検討. 関東産婦誌 $49: 567-$ 572, 2012

12）奥 久人, 松本 貴, 佐伯 愛, 他: 月経時に増 悪しイレウスを併発した回盲部子宮内膜症の一例

外科と婦人科の連携による腹腔鏡補助下回盲部 切除術より。日エンドメトリオーシス会誌 30 ： $74-77,2009$

13）坂本一博, 永易希一, 杉本起一, 他 : 腹腔鏡下に 切除した直腸子宮内膜症の 1 例. 臨外誌 65 ： 1729-1732, 2010

14) Heaps JM, Nieberg RK, Berek JS : Malignant neoplasms arising in endometriosis. Obstet Gynaecol $7: 1023-1028,1990$

15) Thomas EJ : Combining medical and surgical treatment for endometriosis: The best of both worlds? Br J Obstet Gynecol 99:5-8, 1992

16）安井元司, 安藤修久, 野崎英樹, 他：直腸子宮内 膜症癌化の 1 例. 日外会誌 $6: 651-653,1992$

17) Yantiss RK, Clement PB, Young RH : Neoplastic and pre-neoplastic changes in gastrointestinal endometriosis : a study of 17 cases. Am J Surg Pathol 24:513-524, 2000

18）岡本規博, 丸田守人, 松岡 宏, 他 : 腹腔鏡補助 下手術を施行したS状結腸子宮内膜症の 1 例。 日 本大腸肛門病会誌 $56: 123-127,2003$

19）小田木勲, 加藤智弘, 田尻久雄, 他 : 直腸異所性 子宮内膜症の 1 例. Progress of Digestive Endoscopy $68: 158-159,2006$

20）松見泰宇, 袖本武男, 西井 修, 他：難治性の腸 管子宮内膜症に対して腹腔鏡補助下S状結腸部分 切除術が奏功した 1 例. 日産婦内視鏡学会 22 ： 437-441, 2006

21）秦 政輝, 野中英臣, 坂本一博, 他：腸管子宮内 膜症に対する腹腔鏡補助下大腸切除術の 1 例. 日 鏡外会誌 $13: 429-434,2008$

22）古谷正敬, 浅田弘法, 中村修三，他：精査により 診断に至った重症慢性骨盤痛を伴う異所性子宮内 膜症の 2 例. エンドメトリオーシス研会誌 29 : 147-151, 2008

23）大㭇憲一, 小山文一, 中島祥介, 他：腹腔鏡下手 術を施行したS状結腸子宮内膜症の 1 例. 日外科 連会誌 $33: 218-222,2008$

24）奥 久人, 松本 貴, 伊熊健一郎, 他：過敏性腸 炎様の症状を呈した直腸子宮内膜症の 2 症例。 日 エンドメトリオーシス会誌 $30 ：$ 86-90, 2009

25）森脇征史, 明石大輔, 川口 勲, 他：腹腔鏡補助 下に腸管合併切除を施行した腸管子宮内膜症の 2 症例。 日エンドメトリオーシス会誌 $30: 82-85$, 2009

26）高須千絵, 島田光生, 柏原秀也, 他 : 腹胫鏡下に 切除した直腸子宮内膜症の 1 例. 日外科系連会誌 $36: 835-839,2011$

27）石崎哲央, 林田康治, 土田明彦, 他 : 腹腔鏡下高 位前方切除術を行った直腸S状部子宮内膜症の 1 例. 日外科系連会誌 37：1142-1146，2012

28）大木進司, 鈴木 聡, 竹之下誠一, 他：腹脘鏡手 術を施行したS状結腸子宮内膜症の 1 例. 福島医 
誌 $62: 92-96,2012$

29）薮崎紀充, 石山聡治, 宇田裕聡, 他 : 回腸 - 直腸 に同時発症した腸管子宮内膜症に対して腹腔鏡下 手術を施行した 1 例. 日鏡外会誌 $17: 197-202$, 2012

30）竹林克士, 園田寛道, 谷 徹, 他 : 腹腔鏡下手術
で治療しえた 3 力所の稀少部位に発生した子宮内 膜症の 1 例. 日鏡外会誌 $19: 641-646,2014$

31) Vercellini P, Somigliana E, Crosignani PG, et al : Postoperative oral contraceptive exposure and risk of endometrioma recurrence. Am J Obstet Gynecol 198:501-505, 2008

\title{
A Case of Endometriosis in Rectosigmoid Treated by Laparoscopic Surgery
}

\author{
Tomoyuki Ueki, Hiromichi Sonoda, Tomoharu Shimizu, Toru Miyake, \\ Daiji Ikuta, Katsushi Takebayashi, Sachiko Kaida, Hiroya Iida, \\ Tsuyoshi Yamaguchi and Masaji Tani \\ Department of Surgery, Shiga University of Medical Science
}

A 45-year-old woman was referred to a nearby clinic, complaining of left lower abdominal pain. Colonoscopy revealed stenosis of the rectosigmoid, although the biopsy only found inflammatory cells. On the other hand, abdominal contrast-enhanced computed tomography and pelvic magnetic resonance imaging showed tumor lesions in the anterior wall of the rectosigmoid behind the uterine cervix. In the diagnosis, we suspected intestinal endometriosis strongly because of the clinical course and examination results.

Laparoscopic high anterior resection was performed. Histopathologocal findings confirmed the diagnosis of endometriosis of the rectosigmoid. The postoperative course was uneventful and she was discharged from our hospital in the $9^{\text {th }}$ postoperative day.

Key words: intestinal endometriosis, laparoscopic surgery 